\title{
LEMD3 Gene
}

National Cancer Institute

\section{Source}

National Cancer Institute. LEMD3 Gene. NCI Thesaurus. Code C147952.

This gene is involved in inhibition of nuclear import of receptor-regulated SMADs (RSMADs). 